\title{
The Odyssey of 41 Glassmakers
}

\author{
On June 25 and 26, the international specialty glass manufacturer Schott celebrated the $75^{\text {th }}$ \\ anniversary of the "Odyssey of the 41 Glassmakers" from Jena to Western Germany. This \\ measure that was ordered by the American military leadership in Europe in the summer of \\ 1945 after the end of World War II ended with the opening of a new main plant in Mainz in \\ 1952 and, analogous to the division of Germany, also brought about the division into East \\ and West for Schott. It was only the reunification of Germany that enabled the company to \\ overcome the decades of division.
}

World War II and the reign of terror of National Socialism ended at Schott's founding location with the arrival of the American troops in Jena on April 13, 1945, just a few weeks before the official end of the war. However, because the Allies had previously agreed that Thuringia should be part of the Soviet occupation zone after the end of the war, the US troops had to withdraw from the region again. And yet the Americans wanted to secure Schott's know-how as one of the leading specialty glass manufacturers worldwide for themselves and the West. Following the motto "We take the brain," they therefore decided without further ado to take the management and a group of experts with them to the West. The respective individuals had no choice and had to obey the order of the American headquarters.

On June 25 and 26, 1945, two treks with American military trucks set off for an unknown destination. On board were 41

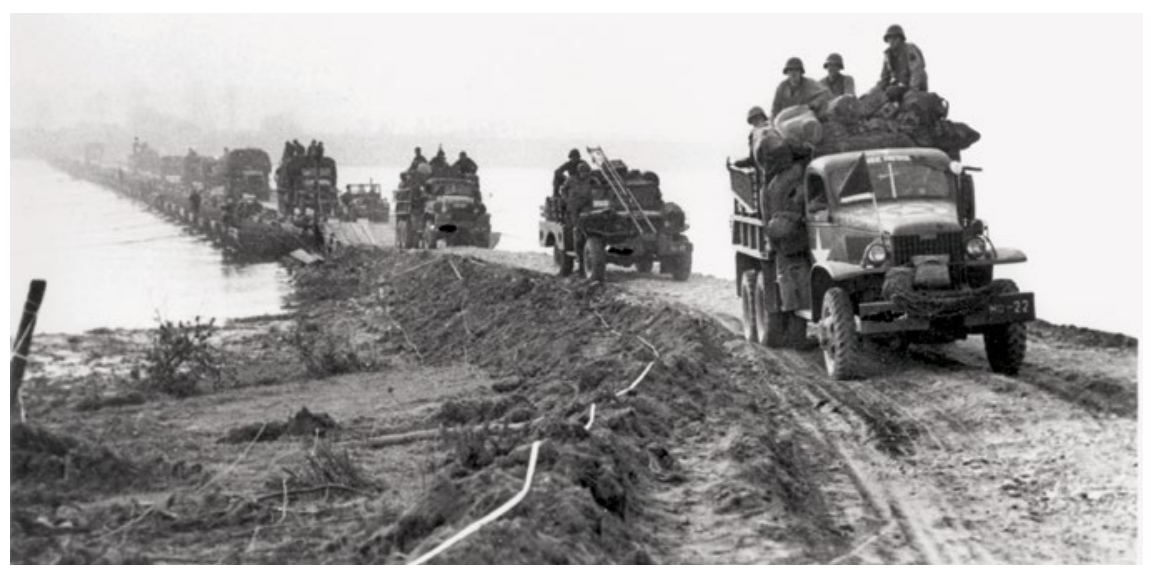

Figure 1 The ' 41 glassmakers' and their families were transported from Jena to the West in two such American military convoys on June 25 and 26, 1945. Each family was assigned a truck to transport their household goods. (@ Schott)

employees and their families, a total of 145 men, women and children (Figure 1). This included the Managing Director Erich Schott, the son of the company founder Otto Schott. The American soldiers first brought the ' 41 glassmakers' to a camp in Heidenheim an der Brenz in Württemberg, from where they were later brought to villages in the surrounding area.

"Today, we can only guess what this meant for these employees and their families at the time. Although they had survived the war and National Socialism, they now had to leave their homes, their homeland, relatives and friends, and had a completely uncertain future ahead of them. That must have been an extremely difficult time for them," says Heinricht, Chairman of the Board of Management of Schott AG.

A period of uncertainty and provisional arrangements began for the ' 41 glassmakers' in Heidenheim who initially had at least the 